\section{Ver Elst}

Mr. D. Ver Elst, Department

Theology and Religious Studies,

KU Leuven.

(orcid.org/0000-0002-6467-7286)

dries.verelst@student.kuleuven.be

DOI: http://dx.doi.

org/10.18820/23099089/actat. v40i2.18

ISSN: 1015-8758 (Print)

ISSN: 2309-9089 (Online)

Acta Theologica 2020

40(2):342-359

Date received:

16 September 2019

Date accepted:

28 October 2020

Date published:

18 December 2020

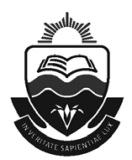

Published by the UFS

http://journals.ufs.ac.za/index.php/at

(c) Creative Commons

With Attribution (CC-BY)

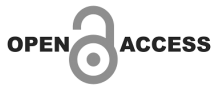

A POWERFUL

ENCOUNTER: THE

RELATION BETWEEN

DIACONIAAND

SPIRITUALITY ${ }^{1}$

\section{ABSTRACT}

Spirituality, when conceived of as a relation with the transcendent, can be experienced in many ways. This article explores how diaconia, when defined broadly as service work, can be a place where this relation is experienced. Based on the reviewed literature, the different ways in which spirituality and diaconia are related, as well as the influence of spirituality on diaconia and of diaconia on spirituality are discussed. On the basis of theoretical and empirical research literature, the article explores concepts such as calling, effectivity of diaconia through spiritual strategies, humbleness, perseverance and coping that influence diaconia. Spiritual transformation through diaconia is discussed by viewing diaconia as a spiritual act and the encounter with a greater good, love, calling, heterotopia and suffering in the practice of diaconia. These different forms of relation are examined critically, as an indication for further research and implementation in theological and communal praxis.

1 I would like to thank my promoter, Annemie Dillen, for all her suggestions regarding content and form. I also thank Anneleen Decoene, Sushil Tiruvanjiam, Gorgette Valabadasse, Omar Shaikhani, Amin Azizi, Waseem Akhtar Usmani, Henk Vandaele, Elke Verstraete, Rinat Allagulov, Prisca Nanda, Jeff Meeuws, fr. Justin, and fr. Kilaiton, for sharing their experiences and creating the right setting for writing; Giverny De Boeck, for her suggestions on calling, and Michiel Herman, Simona Andrejova, and my father Bart Ver Elst, for proofreading. 


\section{INTRODUCTION}

When thinking of spirituality, the first thing that comes to mind for the vast majority of individuals will be traditional rather than individual practices. This causes them to miss out on many opportunities to experience the divine. When defined as everything dealing with and relating to something that transcends the self, spirituality is a very broad concept. It is all that makes life integration possible: people's experiences in this life are viewed as a greater whole, giving them meaning and enabling them to enter into contact with this greater whole through their experiences. This is possible through the "spirit" of man itself, the openness to the idea and the experience of such a transcendent (Hryniuk 2010:16, 22; Puchalski 2012:49). This broad definition contains everything aimed at a transcendent: acts, patterns of thought, and affects. The transcendent is not specified: it could encompass both religious traditions and non-traditional forms of experiencing transcendence.

Diaconia can be a way of relating to, and thus experiencing the transcendent. Diaconia is defined, in this instance, as all service to people or nature out of love for creation. This is not free of contestation. The concept "diaconia" has evolved over time, as Collins $(2014: 76,77)$ highlighted in his search for the roots of the word. In ancient Greek, besides meaning a servant such as, for example, a slave, the substantive diakonos also had a mediating connotation. It was also used for people with a high (or even divine, as in Hermes' case) status, fulfilling diplomatic tasks on the authority of someone who sent them. Early Christianity saw the rise of the office of the deacon, because the latter was serving under the authority of the bishop. The deacon fulfilled various pastoral tasks such as, among others, assisting in liturgy and caring for the poor. In this instance, both connotations were retained, but, as Collins states, throughout history the term developed into a broader concept in the sense that it meant all Christian service work; the mediating connotation was lost (Murphy 1967:840-841; Schiliski \& Schmidt 2008:28-29). Later, a number of authors even argued that all service work is diaconia (Meeuws 2011; Zeitler 2014). All service to man or nature can be regarded as service to God. ${ }^{2}$ It is a form of worshipping the creator, and to the transcendent revealing itself in this practice. However, some authors oppose this statement, and mention that there is an essential difference between Christian and non-Christian service, because the experience is different (Arens 2018:20), and the aim is a divine kingdom instead of a mere human one (Draulans 1996:168). Other authors are also opposed to this "recruiting" of non-Christian service work, because those involved do not want it. Although this is a legitimate concern, the goal, in this instance, is not to recruit in a haughty way, but to learn from the experiences

2 In line with Pope Francis' (2015:83, 96) integral ecology, social and ecological actions are viewed as intrinsically connected. 
of others. The attitude is not one of superiority, but of humble appreciation (Meeuws 2011:288, 305, 312). Only the material that concerns service work is used; the vulnerable other is met in person. It would be interesting to research whether the findings also hold true for service work where this is not the case.

\section{A PROBLEMATIC RELATION}

Some Dutch-speaking authors wrote about an issue they have with diaconia being disconnected from spirituality (Meeuws 2011:19, 97, 104; Arens 2018:9, 37). Churches are confronted with a secularising context and react by focusing on the "core business", which, for most of them, only encompasses liturgy and preaching. This makes diaconia, for some groups, only a way of pulling people into the church, thus diverting the attention away from the real goal, i.e. the needs of others. Others view diaconia as the only task of the church, cuasing it to lose its spirit without connection to other aspects of church life. Diaconia is not limited to the benefit of oneself or others; it also has a "vertical dimension" (Meeuws 2011:245, 281). Besides the horizontal dimension of self-fulfilment for the actor or economic gain for the beneficiary, diaconia is also "good", because it performs a more transcendent good. According to Meeuws, diaconia fulfils not only an economic reciprocity, in which one gives in order to receive, but also a kind of reciprocity in jurisdiction, where people accept the judgment, even when it is to their disadvantage. The reason for this is that they previously received justice, and trust that this will happen again in the future. Similarly, in diaconia, one is giving because one has received. Diaconia is the giving of love, out of the "surplus" one has received, which was not deserved and for which nothing was expected; a love that can be traced back to the gift of existence. A free and pure gift is passed on in diaconia, transcending the biological existence. For this reason, diaconia can be called transcendent (Meeuws 2011:238, 263).

If diaconia is performing a transcendent good, it should be considered a spiritual activity. Meeuws and Arens give other reasons for the spiritual quality of diaconia. It is worship to both man and the transcendent, showing itself in human existence. In the Christian sense, it is also spiritual, for four reasons. First, love for mankind, described in Genesis as "image of god", is also love for the "original", God. Secondly, love is viewed in the Christian tradition as a theological virtue, only possible by God's grace. Thirdly, diaconia fulfils the "option for the poor" in Jesus' preaching and acting and is thus part of following Christ. Lastly, because of Jesus' words "as you did it to one of the least of these my brothers, you did it to me" (Mt. 25:40), tradition speaks of a realis praesentia. Christ is present in vulnerable people. Service to them is service to God (Arens 2018:36; Meeuws 2011:395, 312). 
Diaconia and spirituality are thus related and cannot strictly be separated, as is sometimes the case. This is also in line with salvation history, where deeds and words are one and inseparable. Ancient church followed this trend. As Collins $(2014: 76,77)$ discovered, diaconia had a more mediating meaning, and the early church acted as mediating God's love towards mankind, on the authority of Christ. Social service was an integral part of this mediation, as much as liturgy and preaching, but somewhere in history this unity was lost. Others, however, opine that this unity is still present in the experiences of people active in diaconia. Liselotte Hemeryck, staff member responsible for movement at Welzijnszorg (Care for Well-Being) and Anneleen Decoene, staff member responsible for diaconia at Netwerk Rechtvaardigheid en Vrede (Network for Justice and Peace), two Belgian Christian organisations in the social field, mention that people active in their organisations do not really feel connected to the traditional language that describes spirituality. They are thinking of inspiration or motivation, and intensely experience these concepts (Decoene 2019; Hemeryck 2019). Spirituality and diaconia could possibly be connected in their practice, but not in their traditional forms. This would make the connection invisible in data and spiritual support - if existing - vulnerable to inadequacy. Billiet's $(2016: 148,149)$ analysis of the survey Sociaal-culturele verschuivingen (Sociocultural shifts) in Flanders suggests that this might be a plausible hypothesis, as religiosity or spirituality is not decreasing at the rate at which Catholicism is. This would affirm the theories of sociologists Swatos and Christiano (1999) that there is a process of religious change rather than religious decline.

The following sections suggest, by way of a synthesis of literature concerning at least one or both concepts, some of the ways in which diaconia and spirituality may be related.

\section{SPIRITUALITY INFLUENCES DIACONIA}

Literature reveals a relation of reciprocity between spirituality and diaconia. How can we experience this relation? First, spirituality influences diaconia in at least five ways throughout the whole process of partaking in service work: motivating, functioning in work through humbleness, choosing and executing strategies, coping with difficulties, and persevering with the commitment.

Spirituality can influence the commitment and well-being of volunteers or employees when they experience their activity as a calling. A positive link was found in occupational psychology between a perceived calling and commitment, well-being and motivation, using Dik and Duffy's (2009) definition, in which a calling can come from anything beyond the self, summoning someone to fulfil a particular role in life by providing a sense of meaning for 
the activity. This transcendent can be God, but also, for example, the needs of a society, and offers an integrating perspective on the activity by viewing it as contributing to the greater whole (Dik \& Duffy 2009:427). Žiedelis' (2018) research with nurses in Lithuania shows that there is an influence in the degree in which the experience of a calling is present in the commitment. However, the influence of the work environment was more decisive. Nonetheless, other researchers found a significant influence of a perceived calling on well-being and commitment (Allan et al. 2014:605, 615; Kolodinsky et al. 2018:406, 423). This could also hold true for diaconia, since many people testify to the experience of a "calling" (Colon 2001:B1; Schackleford 2015; Bigg 2018:1). Whether this experience also influences well-being and commitment is a topic for further research.

Spirituality can also influence diaconia in the effectivity of the service. According to the literature, this can occur by stimulating a better sense of purpose. Spirituality can influence this in a negative way, as was the case in the medieval caritas (charity), which was aimed more at the actor's own salvation than at the needs of the receiver, reducing the other to a mere object of care and not fulfilling his/her real needs. But spirituality can also offer a solution to this same problem. By relating to the transcendent and the broader perspective this provokes, the attention can be directed more to the real needs in this situation. Spirituality can cause an attitude of humbleness, profoundly affecting service work. When relating to a transcendent and viewing everything from the transcendent's perspective, people are forced to take on a humble position, relativising egocentric strivings and making it easier to see the real needs of the other and to commit to service more fully. Arens (2018) states that humbleness makes human love flourish, in order for the other to grow. If diaconia is performed because of power, status or joy, motivation will quickly fade, or people will fall into the trap of seeing the other as an object. The humbleness that ends all selfishness can, according to him, only come from faith: recognising not being almighty as an individual and trusting oneself to something bigger (Arens 2018:116, 130). Dillen (2011:76-77; 2002:3, 21; $2017 \mathrm{~b}: 1,6)$ criticises this way of thinking in terms of humbleness, stating that this is only possible for people who are not forced by circumstances to take on a serving position, and this does not give sufficient room for vulnerable people to experience the self-worth attained by giving themselves. She also criticises a rhetoric of self-sacrifice, "serving only God", because it makes criticism impossible, and can hide power mechanisms. It can also divert the attention away from the real needs in the situation. She proposes thinking in terms of self-gift rather than sacrifice, giving all that is possible to fulfil the needs, but with attention to one's own limits and spirituality. Based on this, Arens $(2018: 66,70)$ also writes that real humbleness is a process of reflection and raising awareness. Possible egoism should be a motivating factor to further 
develop a better attitude. The humble attitude of relating to a transcendent can stimulate the effectivity of service work, provided sufficient attention is paid to one's own limits, power and growth.

Spirituality can also help in analysing situations and, consequently, choosing and employing strategies of action. By entering into a relationship with the transcendent, the world is viewed differently. One comes into contact with the inner dimension of the self, thus enabling better contact with others, a more trusting approach, critical of human conventions. An example of this is Scharmer's (2007) Theory U. For him, the evidence-based methods used in the social sector are aimed too much at the past: nothing guarantees that a method, mathematically proven to work in the past, will also work in the future. To find the best approach in the given situation, one must also be open to the circumstances and possibilities. Spirituality can be helpful in this process. He proposes a U-shaped method. First, one "downloads" all the knowledge and methods. Then, in the situation itself, one should let go of everything, in order to see the needs and possibilities (the bottom part of the U-shape). This is what he calls presencing, sensing what the potential for the future is and making it present. This is a spiritual activity, but not a mere introvert one: it is letting go of the old by grounding thought and action in an ultimate reality, making it possible to meet the real other and see the ethical questions. The strategies can then be adapted to these possibilities and questions, thus completing the U-shape (Scharmer, cited in Zeitler 2014). Spirituality can provide possibilities for improving the process of deciding and executing strategies of action in diaconia.

Lastly, taking part in diaconal activities means confronting many hardships and difficulties. Coping strategies need to be developed, in order to deal with these difficulties, not in the least the confrontation with intense suffering. Spirituality can offer some of these strategies. If one's commitment is rooted in the transcendent, there is an ever-lasting safety net to fall back on. Spirituality also offers a language to frame the intense experiences, making them more approachable and relativising them. This influence can also be observed in research. Choi et al. (2008:247, 259) found that informal caregivers in South Carolina found support in spiritual activities, in order to postpone the outsourcing of care to professional institutions for a longer time. Ekedahl and Wengström $(2010: 530,537)$ found that, in Scandinavia, some Christian nurses working with cancer patients used God as a "complaints department", making it easier to cope with the worries and negative feelings. They also found a great deal of help in prayer, entrusting the dying patients' fate to God. 


\section{DIACONIA INFLUENCES SPIRITUALITY}

The biggest potential might lie in investigating the influence diaconia can have on spirituality. If diaconia can be characterised as a spiritual activity, it offers possibilities for people to relate to the divine in a different way, to get a sense of the divine through their service work. This can be a different way of doing theology, of thinking about God. It is more connected to the everyday experiences of people. If theology aims to help people relate to the divine, this should take into account that this relating always happens embodied, in a certain context at a certain moment in time, influenced by all the experiences people gathered throughout their life. If theology could be more connected to these experiences, new, different and possibly richer ways (e.g. diaconia) of relating to the divine could be disclosed.

First, the transcendent can be discovered in diaconia by experiencing the "greater good", which is the objective. If one experiences a good that is not to the benefit of oneself or one's own group, this transcends all that is known. In this way, the transcendent is performed and can be experienced through service work. Doat (2013) gives this a possible evolutionary basis: caring for vulnerable people could have played a crucial role in developing social skills, morality and transcendentality. According to Darwin (1871), because people were more vulnerable than, for example, gorillas, they were forced to live in groups, in order to protect themselves, and thus had to develop social skills and ways of communicating to organise this group life. Archaeological finds show that, in early human history, groups started caring for disabled people (Renfrew 2009:50,61). Doat $(2013: 125,168)$ opines that they might have played a big role in developing societies, since they confronted mankind with its vulnerability more clearly than people who are seemingly able-bodied. By being confronted with vulnerable people, human beings discovered a higher form of morality, which transcended the benefit of the individual or even the group (disabled people made it harder to protect the group; so in this logic, it would not have been useful to care for them). This greater good, which transcends the biological, social and even cultural reality, might have opened the capax dei of mankind, their possibility to relate to something transcendent. This could be compared to what Levinas (1979) describes as the "appeal of the face of the other", summoning individuals by its naked vulnerability to take responsibility, appealing to a good transcending the individual. Meeuws' (2011:220, 281) "primordial gift of existence", which is made present, is also a way of experiencing the transcendent through gratefulness and love. Another way of finding a "higher" good in diaconal activity can be through the need for adapting ethics to the circumstances. Because of this, people are confronted with the need for balancing an "a-cosmic" - because not realisable - "ethics of conviction" and an "ethics of responsibility", taking into account all the 
circumstances that go against ideal norms (Weber 1988, cited in Draulans 1996:139). Diaconia can help people get a sense of ethics, which transcends universally applicable norms, due to the, at times, urgent character of the needs, asking for an ethics of responsibility that acts upon the circumstances aiming at a higher goal. In doing this, it sometimes transcends these apparent universal norms, giving people a sense of ethics that is not reducible to formal statements or rules, a form of ethics aimed at the transcendent.

A second way of experiencing the transcendent in diaconia is through the unconditional love that is made present. Miller-McLemore's (2003:125, 128; $154,157)$ work on parenthood and spirituality suggests that divine love is experienced in a new way in parenthood. Being a parent offers the possibility to learn to recognise God in the chaos of daily family life, not only in silence and tranquillity. Parents can also learn not to aim for perfection, but to entrust it to God. In this way, she corrects traditional thinking about divine love and compares it to maternal love (Stramara 2015:3,25), by approaching it in the multiform and chaotic reality. The same could be said about diaconia, where (divine) love is made present and can be experienced in chaotic everyday reality. This is clearly observed in testimonies from people who are active in l'Arche communities. L'Arche is an organisation, founded by Jean Vanier, based on the idea that, in living together on an equal basis, both people with and without disabilities grow in humanity and spirituality. People with disabilities are valued highly in these communities and are recognised in their capacities for relating to others, who are not restricted by their disabilities. On the contrary, this is where the "assistants", as the people without disabilities are called, can learn from the "core members" with disabilities. They are not focused on achieving something, but enter into relationships fully trusting the other, not having any other goals or benefits than the relationship itself in mind. Confronted with this attitude in the context of living at a slower pace, many assistants testify to a profound growth in their attitude towards life and in spirituality (Harris 1987:322, 325; Thulberry \& Thyer 2014:348, 357; L'Arche International 2018).

In his book, Hryniuk (2010) cites and analyses many assistants' stories. He was able to discern the assistants' general process of growth. Living with the core members, they learn that their identity is not primarily constituted by what they do or achieve, but by loving and relating to others. They learn to replace this identity, which Hryniuk analyses as constructed protection against shame, with acceptance of their whole self in relation. For this, they first have to be confronted with their "darker sides", negative feelings and characteristics, in the fully accepting environment of the communities. Because of this, they also learn to accept God in their life. For Hryniuk, "sin" is a crucial concept. Just like Adam and Eve committed the original sin by denying the relation of trust with 
God, the assistants built up their life wanting to be autonomous, basing their self-worth entirely on their own achievements and the praise they gain for it: they deny God. And just like Adam and Eve, they have to cover themselves up after breaking this relationship, albeit here in layers of achievement (Gen. $2: 21)$. This is based on an image of the human being with which people can only relate for a very short period in their lives, and some (or even most of them) never do (Salenson 2019:36, 46, 102, 109). Through the process of reshaping their identity, the assistants learn that they are primordially existing in relation not only to others, but also to the Other, the first relation with God. They accept their vulnerability in a new life based on love, giving their spirituality an entirely different character (Hryniuk 2010:128, 132, 135, 140, $142,146)$. In this process, their love becomes, what Kornas-Biela (2017:202, 206) calls in John Paul Il's words, "merciful love". This differs from justice as it is based primarily on relationality. Because life in the communities is based on "being together" rather than "caring for", the assistants' love evolves into reciprocal love. If John Paul II (1981, cited in Kornas Biela 2017:198) characterises God's love in this way, the assistants learn to transmit and, in so doing, experience divine love. Hryniuk (2010:125-126, 128, 132, 135, 140, $142,146)$ illustrates this with cited testimonies from l'Arche assistants. The question as to whether this process of accepting a new identity and God's love can also be found in other forms of service work deserves further research.

Thirdly, the influence of diaconia on spirituality can also take the form of developing a humble attitude. Hryniuk (2010:128, 132, 135, 140, 142, 146) describes this as becoming "theonomous", i.e. no longer being autonomous, but trusting in God. This can be learned in relating with people in more vulnerable situations. Since people are fully aware of their limits as human beings, they are more open to the transcendent. This can be understood in Jesus' saying: "Blessed are the poor, for theirs is the Kingdom of God" (Luke 6:20). The biblical poor are not restricted to material poverty, but all marginalised people are included, as they are not expecting anything from worldly or religious authorities, and thus can be fully open to trust in God (Kollar \& Shafiq 2016:59, 65). Arens' theory of humbleness further elaborates this idea, stating that this attitude of humbleness is essential in faith. Without it, true love and faith cannot develop, because people consider themselves to be (partially) God. In learning this humble attitude, it is crucial that diaconia itself is the only end of the action. If other goals are the objective, real contact and reciprocal love become impossible. True growth is possible only when entering service work with the aim of carrying the burden together. Spiritual growth is not possible when diaconia is performed with the aim to growth. It is only a secondary cause of service for the sake of service (Arens 2018:26, $32,120,166)$. 
These last two examples, diaconia offering the spiritual potential for love and humbleness, can be illustrated by testimonies from people at l'Arche. The theologian Henri Nouwen talks about how he gradually learned to adapt to core member Adam's way of communicating and living, discovering that he is not his writings, but in the first place a body relating to others. To reach this insight, he went through what he calls a "dark night", confronted with his incapability to give love fully, breaking all his defence mechanisms and allowing all negativity inside him to emerge. He then learned to accept his limits and experienced "God's first love, which gave him this beautiful self" (Hryniuk 2010:128, 132, 135, 140, 142, 146).

A fourth form of influence of diaconia on spirituality can be found in the literature on "calling". The experience of a calling also implies a caller. A calling cannot only influence well-being and motivation, but also spirituality. Work becomes a way of relating to the transcendent, and thus a spiritual activity. Ekedahl and Wengström's (2010:534) research serves as an example. The nurses they interviewed mentioned that, by praying with patients, this act came to mean something entirely different to them. Their work changed their attitude towards the transcendent: they learned to fully entrust themselves to God, just like the dying patients did. They were also influenced in a more general way. Some of the nurses developed a spirituality entirely of their own, no longer nourished by institutional religion but by their activities in caregiving. Ekedahl and Wengström $(2010: 531,533)$ used the term "Caritas Christians" for these nurses: their spirituality was characterised by caritas ideals mixed with nursing theory. This raises the question as to whether every job can generate its own spirituality. Can the divine be experienced in any form of employment? In the Benedictine tradition, monks are encouraged to approach their manual labour like prayer (Derkse 2003:19, 21; Benedictus 2000:21, 23, 25, 31, 59, 60; Gradu 2015:226, 233). Luther's (cited in Wingren 2018:84, 90) reaction to cloister spirituality could also be understood in this way. According to him, all human activity is a calling to spread God's love. Could there be an essential difference between the spirituality of diaconia and other activities, or is it only a form among many others? One could assume that, given the personal or indirect contact with vulnerable people or nature and the focus on love in diaconia, the experience might have more spiritual potential. This requires further research. Literature on the spiritual potential of diaconia does not pay much attention to calling, and certainly not the spiritual potential of calling experiences (Meeuws 2011:363; Arens 2018; Salenson 2019). Literature on calling only considers diaconia in specific cases. Cahalan's compilation analyses calling in all life phases and only addresses diaconia in adolescence and middle adulthood, when a lack of activities viewed as meaningful is sometimes compensated with volunteering. Although their broad conception of calling can be interesting for the diaconal field, as well as the need for the 
experience throughout all life phases and the need for role models and guides opening the possibilities and supporting some callings, the lack of attention for diaconia is remarkable (Cahalan \& Miller-McLemore 2017:12, 33, 26, 30 , $67,92,123,148)$.

A fifth way in which diaconia might influence spirituality relating to the transcendent is that it breaks with everyday life. The "otherness" of diaconia might stimulate an openness to something transcending everyday reality. Dillen (2013: 261, 269) defines diaconia as a "heterotopia", which, unlike a utopia, does exist, but is aimed at something "different", or simply is different. Dillen believes that this provides theology with the possibilities to discover new sources of encounters with God, for example, by experiencing harmony and unity. She provides an example from her own experiences. In a eucharistic celebration in a refugee centre, the vulnerability of the child Jesus became more vivid for her than ever. L'Arche can also be an example of a heterotopia as in the story of Thomas, a university student who at last felt free to "be who he is, and not who he has to be" (Hryniuk 2010:127). Vandenhoeck (2017:165, 178) calls care facilities "holy ground". She observed how the spirituality of many chaplains and chaplains-in-formation developed throughout their professional experiences, as they faced intense life experiences in a warm and loving environment.

A last form of the influence of diaconia on spirituality, as found in literature, is through confrontation with suffering, refocusing people on the essence of their existence, and helping them view their own suffering differently. In research with chaplains working with war veterans, the confrontation with immense and pointless suffering paradoxically had a positive influence on the spirituality of many chaplains (McCormick et al. 2017:1, 17, in Vandenhoeck 2017:168). Testimonies from l'Arche also show this. For example, "Paula" tells how she needed the experience of standing by core member "Tracy" in her suffering, in order to "accept their brokenness" and the limits of human existence together (Hryniuk 2010:146, 150). Arens (2018:108) also notes this influence in the Jewish law, where remembering the suffering in slavery in Egypt is used to encourage moral behaviour. In the same way, according to Arens, confrontation with suffering in diaconia frees the love in people. Salenson $(2019: 56,60)$ also believes that this confrontation with suffering changes peoples' image of God. Terms such as "the almighty" can no longer be used in the same way, when one is confronted with undeserved suffering. Power becomes power in vulnerability, which is revealed in the evil of suffering. The supposed superiority of people is torn down. At the same time, God also becomes vulnerable from a human point of view: revelation must be accepted, in order to welcome God in the human life. 


\section{APPEALING TO CHURCH AND THEOLOGY}

This analysis also implies an appeal. If, in diaconia, the divine can be experienced in so many ways, religious communities should consider how to incorporate this in their theology and practices. Hryniuk (2010:272, 281, 283) gives an example by defining life in l'Arche as asceticism. Etymologically, this means "practice", in this case practice in living out of God's love. Christian liturgy could also explore possibilities for paying attention to diaconia, by placing more emphasis on the aspects of sharing, community and service, or even by being an act of service itself. Using traditional music or other inculturation elements are ways of supporting marginalised groups (Hernandez Hernandez 2017:185). Celebrations across the border fence in Mexico are also a good example (Hernandez Hernandez 2017). The "service church model", where the church is present alongside the poor, could also be an inspiring concept (Martinez \& Muella 2017:122). Martinez and Muella (2017:117) even opine that the church should learn from intensely faithful communities that are considered to be "lost causes".

The most promising methods seem to be those exploring the spiritual potential of the existing diaconal activity. Meeuws designed a model of "diaconal mystagogy". Mystagogy is the process where a myste, introduced into "secrets" of faith by a mystagogue, learns to discover God in his/her experiences. In Meeuws' model of diaconal mystagogy, besides the model of mystagogical diaconia where volunteers are taught to recognise the divine, the church itself becomes a myste. In the experiences of diaconal workers, the community gets to know God better. This is only possible when the leading figures of the community are in touch with these experiences of diaconal work. Meeuws proposes that they could write these experiences down, to create a distance, in order to recognise what is showing in the moment. They should then reappropriate their experiences, for which he proposes the method of lectio divina (Meeuws 2011:366, 414), a medieval method of reading, pondering, praying, and contemplating (Robertson 2011:90, 91).

Lastly, theology could also benefit from taking into account the experiences of people active in diaconia. Theology itself would grow, as more sources of the encounter with the divine can be explored. But the output of theologians would also be more relatable to people active in diaconia, as they can feed their own spirituality and become more sensitive to the divine in their own practice. A few examples of this form of doing theology can be found in the literature. The Dutch manual for diaconia studies Diaconaal doen doordacht features a chapter in which conversations with people active in diaconia are used for reflection on theological themes, and for gaining new links and insights. However, they still apply the traditional conceptual framework rather quickly, thus reducing the experience to what is already known (Arts-Honselaar et al. 
2018:231, 255). Schuilenga (2003:12, 14, 57, 62-63) warns against this trap of applying one's own interests and assumptions on stories, making them no longer relatable to the actors and restricting the potential to learn. Borgman (cited in Schuilenga 2003:16, 138) states that this kind of research should function as an antenna, detecting traces of the divine, amplifying them and passing them on. In her own research, Schuilenga first lets the experiences of suffering and joy speak for themselves. Thereafter, she carefully tries to detect grace in the stories, motivated by the theory that grace only functions as such when it is recognised and used as nourishment for life. Schuilenga's (2003: 18-20, 25, 29, 49) research aims at a true metanoia, a conversion, by putting unheard stories on the front plan of academic theology. By letting the experiences of people active in the diaconal field speak for themselves, theology can grow and become more relatable, and thus better fulfil the goal of nourishing the faith of people.

\section{CONCLUSION}

Spirituality and diaconia are connected in several ways. Spirituality can influence diaconia throughout the entire process of being active: from the motivation through a calling experience, to the choice and execution of strategies by humbleness and transcendental perspectives, to persevering through coping mechanisms. Diaconia can also influence spirituality, as it can be considered a spiritual activity and thus change the whole of relating to the transcendent. This can happen through the transcending perspective of the ethical reflection diaconia provokes. Another way is in the love that is made present, in which divine love is experienced anew. Diaconia can influence spirituality by stimulating a humble attitude necessary to relate to the transcendent. The experience of a calling can also influence spirituality, as it implies a caller. The heterotopical character of diaconia can point to the transcendent. Lastly, the confrontation with suffering can lead people to experience the divine and existence differently.

More emphasis could be placed on the relation between spirituality and diaconia in church structures and activities. Theology could also benefit from taking into account the source of divine experience, which diaconia can be. This would not only broaden the perspective of academic theology by taking people's experiences in diaconia seriously, without applying one's own presumptions and interests; the output of study could also appeal more to the general public. In that way, theology could cater more to the needs of people for literature with which they can identify and which feeds their spiritual life and heightens their awareness of the divine. 


\section{BIBLIOGRAPHY}

Allan, B.A., Duffy, R.D., Autin, K.L. \& Douglass, R.P.

2013. Living a calling and work well-being. A longitudinal study. Journal of Counselling Psychology 61(4):605-615. https://doi.org/10.1037/cou0000042

ARENS, A.

2018. Als God gebeurt. Over christelijk geloof en inzet voor kwetsbare mensen. Antwerpen: Halewijn.

ARTS-HONSELAAR, H. (ED.)

2018. Diaconaal doen doordacht. Kampen: Kok.

\section{BENEDICTUS}

2000. De regel van Sint-Benedictus. Translated from Latin by V. Hunink. Amsterdam: Athenaeum-Polak \& Van Gennep.

BIGG, $\mathrm{H}$.

2018. How I found my calling as a volunteer. Joining a global telehealth program can profoundly change a child's life and yours! Contemporary Pediatrics 35(10):1-4.

BILLIET, J.

2016. De evolutie van de betrokkenheid bij de katholieke kerk in Vlaanderen 1996-2015. In: D. Verlet (red.), 20 jaar peilen in Vlaanderen! De survey sociale en culturele verschuivingen in Vlaanderen (Sint-Niklaas: Room), pp. 125-149.

Cahalan, K.A. \& Miller-McLemoRe, B.J. (EDS.)

2017. Calling all years good. Christian vocation throughout life's seasons. Grand Rapids, MI: Wm B. Eerdmans.

ChOI, G., TIRRITO, T. \& MiLLS, F.

2008. Caregiver's spirituality and its influence on maintaining the elderly and disabled in a home environment. Journal of Gerontological Social Work 51(34):247-259. https://doi.org/10.1080/01634370802039528

COLLINS, J.N.

2014. Diakonia studies. Oxford: Oxford University Press. https://doi.org/10.1093/ac prof:oso/9780199367573.001.0001

COLON, V.

2001. Busy volunteer sees work with children as his calling. Courier Post 16 February, p. B1.

DARWIN, C.

1871. The descent of man and selection in relation to sex. London: John Murray. https://doi.org/10.5962/bhl.title.24784 
Decoene, A.

2019. Informal conversation, 24 April [with permission].

DERKSE, W.

2003. Een levensregel voor beginners. Benedictijnse spiritualiteit voor het dagelijkse leven. Tielt: Lannoo.

DIK, B.J. \& DuFFY, R.D.

2009. Calling and vocation at work: Definitions and prospects for research and practice. The Counseling Psychologist 37(3):424-450. https://doi.org/10.1177/ 0011000008316430

Dillen, A.

2002. Het is zaliger te geven dan te ontvangen. Naastenliefde en eigenliefde in ouder-kindrelaties volgens Ivan Boszormenyi-Nagy. Tijdschrift voor Familietherapie 8(1):3-21. https://doi.org/10.13109/diac.2011.2.1.66

2011. Caritas: Powerful ecclesiastical salvific action. Aspects of diaconal service in light of power mechanisms. Diaconia 1(1):66-80. https://doi. org/10.14220/9783737001977.261

2013. The complex relationship between body and mind as a key for a renewed Catholic reflection on diaconal work. In: S. Miller (ed.), Exploring the boundaries of bodiliness. Theological and interdisciplinary approaches to the human condition, 9 (Göttingen: Vienna University Press), pp. 261-269.

2017a. Kerk en diaconie, asiel en samenleving. Diakonie \& Parochie 30(4):10-13.

2017b. Beyond a sacrificial spirituality. Enhancing flourishing pastoral ministers. HTS Teologiese Studies/Theological Studies 73(4):2-6. https://doi.org/10.4102/hts. v73i4.4694

DOAT, D.

2013. Theology and human evolution. An original hypothesis based on the spiritual experience of L'Arche communities. A Christian reflection on human fragility and its consequences for Christian community-building. Journal of Religion, Disability \& Health 17(2):125-168. https://doi.org/10.1080/15228967.2012.731879

DRAULANS, V.

1996. Traditie met toekomst? Sociale beweging en christelijke inspiratie. Leuven: Acco.

EKEDAHL, M.-A. \& Wengström, Y.

2010. Caritas, spirituality and religiosity in nurses' coping. European Journal of Cancer Care 19(4):530-537. https://doi.org/10.1111/j.1365-2354.2009.01089.x

\section{FRANCISCUS}

2015. Laudato Si. Translated from Latin by H. Kretzers. Utrecht: Libertas Pascal. 
GRADU, D.

2015. Ora et labora. Paradigmes du modèle monacal médiéval chez Chrétien de Troyes. Anastasis 2(1):226-233.

HARRIS, G.

1987. In the field - L'Arche. Homes for people who are mentally retarded. Journal of Counseling and Development 65(6):322-325. https://doi. org/10.1002/j.1556-6676.1987.tb01298.x

HEMERYCK, L.

2019. E-mail correspondence to Dries Ver Elst, 30 April [with permission].

Hernandez Hernandez, V.

2017. Liturgy and servant catechesis. Mission Studies 33(3):175-189.

HRYNIUK, M.

2010. Theology, disability, and spiritual transformation. Learning from the communities of l'Arche. Amherst: Cambria Press.

KOLLAR, N.R. \& SHAFIQ, M.

2016. Poverty and wealth in Judaism, Christianity and Islam. New York: Palgrave Macmillan. https://doi.org/10.1057/978-1-349-94850-5

Kolodinsky, R.W., Ritchie, W.J. \& Wayne, K.A.

2018. Meaningful engagement. Impacts of a "calling". Work orientation and perceived leadership support. Journal of Management and Organization 24(3):406423. https://doi.org/10.1017/jmo.2017.19

KORNAS-BIELA, D.

2017. Jean Vanier and l'Arche as a witness of merciful love. Journal for Perspectives of Economic, Political and Social Integration 23(1):195-208. https://doi.org/10.1515/ pepsi-2017-0010

L'ARCHE INTERNATIONAL

2018. In the world. [Online.] Retrieved from: https://www.larche.org/en/in-theworld\#all [2 November 2018].

LEVINAS, E.

1979. Le temps et l'autre. Montpellier: Fata Morgana.

Martinez, S. \& Muella, P. 2017. A simple church, seed of the kingdom. Mission Studies 33(3):115-131.

McCormick, W.H., Carroll, T.D., Slagel, B.A., Drescher, K.D., NieuWsa, J.A., CURRIER, J.M.

2017. Professional quality of life and changes in spirituality among VHA chaplains. A mixed-methods investigation. Journal of Health Care Chaplaincy 23(3):1-17. https:// doi.org/10.1080/08854726.2017.1295675 
MeEuWs, $\mathrm{H}$.

2011. Diaconie. Van grondslagenonderzoek tot een pleidooi voor een diaconale mystagogie. Gorinchem: Narratio.

MilleR-McLemore, B.J.

2003. Let the children come. Reimagining childhood from a Christian perspective. San Francisco, CA: Wiley.

MuRPhY, F.X.

1967. Diaconia. In: Catholic University of America, New Catholic encyclopedia (New York: McGraw-Hill), pp. 840-841.

PuChALSKI, C.M.

2012. Spirituality in the cancer trajectory. Annals of Oncology 26(3):49-55. https:// doi.org/10.1093/annonc/mds088

RenfREW, C.

2009. Neanderthal symbolic behavior? In: C. Renfrew \& I. Morley (eds), Becoming human. Innovation in prehistoric material and spiritual culture (Cambridge: Cambridge University Press), pp. 50-61.

ROBERTSON, D.

2011. Lectio divina and literary criticism. From John Cassian to Stanley Fish. Cistercian Studies Quarterly 46(1):83-93.

SALENSON, C.

2019. Ontwapenende kracht. Antwerpen: Halewijn.

SCHARMER, O.C.

2007. Theory U. Leading from the future as it emerges. Cambridge: Society for Organizational Learning.

SCHILISKI, M. \& SCHMIDT, H.

2008. Diakonia today. In: H.D. Betz, D.S. Browning, B. Janowski \& E. Jüngel (eds.), Religion past and present, 4 (Leiden: Brill), pp. 28-29.

SCHUILENGA, M.

2003. God in de marge. Antwerpen: Halewijn.

SHACKLEFORD, L.

2015. Hospital volunteer heeds calling. Spartanburg Herald, 4 January.

STRAMARA, D.

2015. St. Francis de Sales and the maternal love of God. Magistra 21(2):3-27.

SWATOS, W.H. \& ChRISTIAN, K.J.

1999. Secularization theory. The course of a concept. Sociology of Religion 60(3):209-228. https://doi.org/10.2307/3711934 
THULBERRY, S.C. \& THYER, B.A. 2014. The l'Arche program for persons with disabilities. Routledge Journal of Human Behavior in the Social Environment 24(3):348-357. https://doi.org/10.108 0/10911359.2013.831012

\section{VANDENHOECK, A.}

2017. Nooit alleen. Over de spiritualiteit van de pastor. In: M. Steen (ed.), Gidsen die begeesteren. Over pastoraal leiderschap (Antwerpen: Halewijn), pp. 165-178.

WINGREN, G.

2018. Luther on vocation. A twenty-first-century theological-literary reading. Dialog 57(2):84-90. https://doi.org/10.1111/dial.12387

ZEITLER, U.

2014. Spirituality in diaconia. A reinterpretation of diaconal professionalism within the framework of theory U. Scandinavian Journal for Leadership \& Theology 1(1), https://doi.org/10.1177/0193945918767631

ŽIEDELIS, A.

2018. Perceived calling and work engagement among nurses. Western Journal of Nursing Research. https://doi.org/10.1177/0193945918767631

$\begin{array}{ll}\text { Keywords } & \text { Trefwoorde } \\ \text { Spirituality } & \text { Spiritualiteit } \\ \text { Diaconia } & \text { Diakonia } \\ \text { Practical theology } & \text { Praktiese teologie }\end{array}$

